\title{
Psychoanalysis in Israel: New Beginnings, Old Trajectories
}

\author{
Eran J. Rolnik (Tel-Aviv)
}

\begin{abstract}
The arrival of psychoanalysis in pre-state Israel in the early $20^{\text {th }}$ century presents a unique chapter in the history of psychoanalysis. The paper explores the encounter between psychoanalytic expertise, Judaism, Modern Hebrew culture and the Zionist revolution. It offers a look at the relationship between psychoanalysis and a wider community, and follows the life and work of Jewish psychoanalysts during World War II. The coming of psychoanalysis to pre-state Israel, where it rapidly penetrated the discourse of pedagogy, literature, medicine, and politics, becoming a popular therapeutic to establish its identity in the face of its manifold European pasts and discipline, is regarded as an integral part of a Jewish immigrant society's struggle with its conflict-ridden Middle Eastern present.
\end{abstract}

Keywords: psychoanalysis, Zionism, Eitingon, kibbuz, immigration, Freud, ArabIsraeli conflict, Third Reich

Few chapters in the historiography of psychoanalysis are as densely packed with trans-cultural, ideological, institutional and moral issues as the coming of psychoanalysis to Jewish Palestine - a geopolitical space which bears some of the deepest scars of twentieth-century European, and in particular German, history. The present essay aims at identifying different levels of reception of psychoanalysis before, during, and after the migration of German-speaking Freudians to Mandate Palestine. During this period, the reception of psychoanalysis was anything but straightforward. It thus resembled the heteronomic reception in other parts of the world. I shall therefore first try to identify several points of entry of psychoanalysis into Hebrew culture; then, I shall argue that, hidden beneath the elective affinity which early Zionists professed to find in Freud's theory, an inherent tension, at times even an evident contradiction in terms, began to emerge. 


\section{Freudian Man and the New Man of the Zionist Revolution}

As the place of origin of the dynamic unconscious, Freud's Vienna stood at the crossroad between several frontiers: It stood at the frontier between East and West; it stood at the frontier between enlightenment and romanticism no less than at the frontier of modernity. It also stood at the frontier between socialism and anti-Semitism, and finally, at the frontier between psychoanalysis and Jewish nationalism (Theodor Herzl).

The contributions of Joseph Breuer, Wilhelm Fliess and Freud are often examined in the light of the scientific discourse on race which flooded European thought in the second half of the nineteenth century. The interest in the human body and in sexuality did not fail to impinge upon the self-perception of the leading figures in Zionist thought. Thus, both the neurologist Max Nordau and Theodor Herzl addressed in their writings, explicitly or implicitly, the issue of the sexual identity of the Jew and reflected upon its consequences on the historical fate of the Jewish people (Gluzman, 1997; Bunzl, 1997; Boyarin, 1997). At the Second Zionist Congress held in Basel in 1898, Nordau referred to Zionism as being the main political remedy for the resurrection of the young Jew, whose body had been ravaged by eighteen centuries of exile in the Diaspora. He described the Jew as a sick and degenerate being, much in need of a healthy relationship with his homeland and a stable marriage. Despite its biologistic rhetoric, the degeneracy paradigm was not as deterministic as it might seem. One could, for instance, alleviate or even stop the degenerative process by living virtuously, that is, by adopting a lifestyle based on principles of moral rigor, health, normalcy, beauty, self-discipline, responsibility and duty, cleanliness, and masculine strength. These ideals were promoted in hygiene societies, leagues against prostitution, temperance movements, associations for eugenic policies, and clubs for physical education such as Max Nordau's liberal Zionist Maccabi which was supposed to produce healthy muscle Jews (Brunner, 1991; Berkowitz, 1993; Gilman, 1993; Hart, 2000; Efron, 2001).

Freud's early writings present a striking contrast to both the established paradigm and the Jewish response. With the completion of Studies on Hysteria in 1895, explicit rejections of hereditary conception of neuroses became a regular feature in Freud's contributions. He forcefully disapproved of ethno-racial and even historical explanations for mental problems and harshly criticized those among his disciples who tried to tie the problems of the Jewish people to his teachings. According to Freud, psychological problems should be articulated in psychological terms, whilst the term degeneration expressed a historical view, which held that there had once existed a perfect race whose offspring had slowly deteriorated. 
This perfect people did never exist, thus the term degenerate must not be used to describe either oneself or others (cf. Spiegel, 1986). Furthermore, this preoccupation with the Jewish question, even under a scientific pretense, might exile psychoanalysis to the fringe of the intellectual and scientific discourse of the time, and Freud's followers were often warned not to transform psychoanalysis into a national Jewish issue. ${ }^{1}$

A case in point is Max Eitingon's initial encounter with Freud in 1907. At the age of twenty-six, Eitingon came to Vienna and participated as the first guest from abroad in two of the psychoanalytic Wednesday Meetings. The record of the meetings captured a telling exchange between Freud and the young resident in psychiatry from Zurich. In response to Eitingon's questions whether Jews were especially prone to suffer from neurosis and whether a virtual "social factor" should be postulated, along with sexual motives, in the development of neurosis, Freud remarked that "the questions raised by Mr. Eitingon are indicative of the tendency of our Swiss colleagues to deny the theory regarding the sexual etiology of the neuroses." 2

Eitingon's ethnic and social sensibilities may have interfered at that time with his ability to grasp the radical essence of Freud's conception of sexuality. However, both his future activities within the psychoanalytic movement and his early identification with the Zionist idea bear witness to his preoccupation with Jewish identity and social solidarity. ${ }^{3}$

Notwithstanding Freud's reservations, psychoanalysis was all the more popular among the champions of Jewish-national particularism, who considered the new discipline as a fusion of radicalism and tradition and tried to enlist it for their own political ends. The relation of Jewish particularism to the universalism of European Enlightenment here also gained expression when Freud's early positivist ideas were welcomed as a form of quasi-scientific support for Zionism's romantic endeavor of reconstructing a unified (and unifying) national past.

The tension between the cultural heritage and past of individual immigrants on the one hand, and, on the other hand, the tendency of Zionist ideology to construct a collective past has been frequently discussed in the historiography of the Jewish society of émigrés in the British Mandate (cf. Wistrich \& Ohana, 1995; Sternhell, 1986). From the onset of political Zionism, the need to build a society with a fixed, distinct identity presupposed the creation of a Zionist supernarrative, that is to say, a narrative capable of embracing and overshadowing manifold historical experiences, cultural affiliations, and ethnic sensibilities, which, however, would still tend to emerge from underneath the surface. As is possible 
to observe in national movements in general, the Zionist movement developed an instrumental relation to the past, thereby attempting to give its followers the impression of a collective present and future through the construction of a unitary collective-mythological past. The emerging image of the Jewish immigrant to Mandate Palestine itself served this purpose. This image was that of a newcomer who had freed himself from the chains of an oppressive past, i. e. that of a person presented in terms which were in part historical, in part abstract and mythical, who could henceforth determine his or her own fate. Among the images of the new Jew, sexuality and gender played a central role. Sexuality, in the Freudian sense of the word, served as the means thanks to which the young Jew would transcend the barriers both of the previous generations and of tradition.

As early as 1920, Ernest Jones reported to Freud of a conversation he had held with Chaim Weizman, in which the Zionist leader took pride in those poor Galician immigrants who arrive in Palestine with no clothes but "[with] one hand holding Marx's Capital and in the other, Freud's Interpretation of Dreams.” ${ }^{4}$ Despite the essential conflict between the constructivist-utopian characteristics of socialism in its Soviet version and the social pessimism manifest in Freud's later writings, Zionist readers reviewing psychoanalytic publications preferred to bridge the gap between these different perceptions of Man by a highly selective reading of psychoanalytic theory. The Zionist folklorist and historian Alther Druyanov, in 1910, sought to direct Freud's attention to the similarities between the novel theory formulated in the Interpretation of Dreams and the interpretations of dreams in Kabbalist and Talmudic literature. "Personally I find a more striking resemblance between my ideas on dreams and those of the ancient Greeks" was Freud's response to Druyanov, thus indicating his preference for a universalistic rather than for a particularistic stance. ${ }^{5}$

\section{Oedipus in the Kibbutz}

In the first half of the 1920's, three of Freud's followers, viz. Siegfried Bernfeld, David Eder, and Dorian Feigenbaum, attempted to reconcile their activities in the Zionist movement with their commitment to the ideas of psychoanalysis (cf. Hobman, 1945). ${ }^{6}$ After World War One, the presence of Jewish war refugees in Vienna enabled Siegfried Bernfeld to bring together ideas from the fields of philanthropy, Marxism, Jewish nationalism and progressive education (Ekstein, 1979; Hoffer, 1981; Bunzl, 1992). Bernfeld repeatedly emphasized that youth are naturally endowed with moral and spiritual sensitivity and that they are graced with natural rebellion against injustice. Bernfeld's Jewish Order of Youth had a central role in 
transferring the content and terminology of the German cultural youth movement to the Zionist youth movement Ha-Shomer Ha-Zair (The Youth Guard). ${ }^{7}$ The psychological-historical analysis offered by Bernfeld of the problem of the split self-identity of Jewish-German youth was based on the Freudian concept of repression. He was recognized at the time as the thinker who had found the key to the hearts of the youth, the main target audience of the Zionist movement. When twenty three years old Meir Yaari, co-founder of theViennese branch of Ha-Shomer Ha-Zair, arrived in Palestine in 1920 with a group of young settlers, the impact of Bernfeld's and Freud's ideas on his social outlook was evident:

I want you to become acquainted with Freud and his school in a precise fashion, I don't know whether many of us can accurately grasp his theory, yet I hope that it will at least cleanse the charged atmosphere. I want to sanctify the drive through this experience. Please be aware of the power in you, when masculine eroticism unites you in spite of your inner resistance. ${ }^{8}$

The drive, or the libido, served Yaari as a synonym for inner truth. With his colorful language Yaari represented the tension experienced by Freud's romantic readers between their rationalism on the one hand, and the concept of the Unconscious on the other:

I must dissect and cut into the thought like a cold razor. Yet I become aware that psychoanalysis, in its determinist manner, delves into the depths, elucidating them only to further enhance their mystery [...] Without a spark of creativity, without unhindered obsession, without an act of autonomic free will, one will not penetrate into the core, will not experience and will not create [...] I seek with all my might to penetrate into my Unconscious world and expose myself. I feel this is the only way to independence, only in this manner can one grow. As you see, I am speaking in Freud's words. ${ }^{9}$

It is doubtful whether Yaari's faith in the ability of the autonomous free will to penetrate into the core could be designated as particularly Freudian. His romantic version of the Freudian sexual revolution was marked by excessive optimism. The emphasis on the repressive role of society or on the inherent flaws in the model 
of the nuclear family were far from Freud's heart, although to his early followers it had seemed that he might have been a possible partner for reformist appeals. The youth movement's role was to put an end to sexual hypocrisy and lies, and to remove the creative powerlessness which hindered the path of development of young men and women, the very same erotic dullness which stereotypically characterized the young Jew. MeirYaari spoke often of the pure and open-hearted generation which had arrived in Palestine, a generation which had freed itself from the hysterical nervousness of its parents as well as from the sanctimoniousbourgeois corruption of the instincts.

In the early 1920s, as members of Ha-Shomer Ha-Zair settled in agriculturally based collectives known as kibbutzim, the educational leadership of the movement argued that psychoanalytically informed education was the key to raising children free of bourgeois neuroses. They established strong ties with several European analysts, translated and published psychoanalytic texts, insisted that educators be analysed or, at least, psychoanalytically informed, and built a complex educational system founded on their particular understanding of Freudian insights. According to their firm conviction, psychoanalysis was to be seen as an overall prophylactic means that was meant to safeguard the mental health of the community as a whole. In accordance with this conviction they had, the children in the kibbutz spent most of their waking hours in company of nurses, educators and teachers - the parents were allowed to see their children usually for two hours at most every day. This reflected the belief of kibbutz pedagogues that parental influence on children should be lessened. The pedagogues believed indeed that under such conditions an essential change in the oedipal situation would yield and that the children's exposure to the primal scene would be minimal. Under the pretext of solving oedipal conflicts and of ensuring youth's independence, the children's homes in the kibbutz became in fact greenhouses in which children were trained for their full and harmonic integration into kibbutz society, which from the 1940's onwards was looking for Russian models in addition to the German models in matters both ideological and practical. Thus, the child's first encounter with the urge to abandon his will in accordance with the group's demands took place along with the displacement from his parent's home and becoming a member of a tribal group of children of the same age, which would be an inseparable part of his life until he reached adulthood. In those years, the child incorporated one of the most important principles, which would accompany him throughout his adult life: one's own superego and the ideals of the group are one and the same (cf. Rapaport, 1958; Bettelheim, 1969; Liban \& Goldman, 2000; Peled, 2002). 


\section{Early Freudians and their Analysands}

As seen in the case of communal child rearing in the kibbutz, through psychoanalysis, certain practices in the fields of education and health were implemented, which were seen to serve different rational and ideological goals. While kibbutz pedagogues were trying to find a place for psychoanalysis in the socialist and romantic ethos of collective education, two of Freud's students attempted to bring clinical psychoanalysis to other segments of the Yishuv. In the early 1920s, the debate on the tenets of psychoanalysis took place at the watershed of two conceptions - an ideological-political conception on the one hand, and a scientific-therapeutic one on the other hand. The division between these two facets of Freudianism was far from clear-cut. It does still not necessarily represent the congruency that existed between the scientifico-therapeutic and the ideological discourses.

The psychoanalytic meetings were led, on the one hand, by David Eder (1866-1936), a founding member of the London Psychoanalytic Society and the chairman of the Zionist Executive Council from 1919 to 1924, who spent part of his time in Palestine as a member of one of the Zionist Commissions, and, on the other hand, by Dorian Feigenbaum, a psychoanalyst from Vienna. They were joined by the philosopher Hugo Bergman, the ophthalmologist Arie Feigenbaum, Siegfried Van Friesland, an advocate from Rotterdam who had served as Dutch diplomatic attaché and later as treasurer of the Zionist Agency, and the educator Gerta Obernik. The group started to meet in 1922 on a regular basis, reading and discussing psychoanalytic literature, in what seemed to be the beginning of psychoanalytic activity according to the founding Viennese model (Bergman, 1922). ${ }^{10}$ Eder and Dorian Feigenbaum gave a number of introductory lectures on the analysis of dreams and on the investigations into various forms of parapraxis. However, the meetings came to an end sometime in 1924 with Eder's departure to London.

Dorian Feigenbaum, who had been appointed director of the psychiatric hospital Ezrat Nashim in Jerusalem (the only mental institution in Mandate Palestine), attempted to introduce the local medical community to psychoanalytic theory. He delivered a number of lectures on the interpretation of dreams and the psychopathology of everyday life. In April 1923, he was invited to deliver a lecture series on psychoanalysis for a Jerusalem audience which included physicians, educators and German delegates visiting in Palestine. The lecture series was entitled The Mind in Mental Illness and Health; it was to include three lectures, The Unconscious Freudian Dream Theory, and The Modern Theory of Neuroses. The outraged responses to Feigenbaum's first lecture, however, led the hospital's 
directorship to stop the lecture series. Shortly thereafter, Feigenbaum was fired from his job ("an act of villainy has been committed," Bergman wrote in his diary) and left for New-York. ${ }^{11}$ Thus, the first attempt to incorporate psychoanalytic theory into the clinical framework was brought to an abrupt end (Bergman, 1985; Moses, 1998; Rolnik, 2002, 2007; Windhager, 2002).

It appears that Feigenbaum had been already aware of the need to alert his audience of the danger of a superficial and trendy implementation of psychoanalysis, of the kind he would see thriving among the young immigrants. Indeed, in 1924, shortly before Eder and Dorian Feigenbaum left Palestine, the official Englishlanguage journal of the psychoanalytic movement published a review article on psychoanalysis in Palestine in which some author anonymously declared that:

in certain quarters (especially among the young immigrants) there is a tendency to introduce so-called psychoanalysis far too carelessly, and in a fashionable and vulgarized form. This, quite obviously, is doing harm, and it is most necessary that psychoanalysis should interfere in the direction of correct exposition and, above all, in checking this injurious growth. ${ }^{12}$

The pioneering attempts by Feigenbaum and Eder to strengthen psychoanalytic theory in Palestine did not blossom into the foundation of a local association which would be the center of clinical activity. Freud's name at the time remained therefore linked to the social and utopian aspirations of the Zionist youth movements of the time.

\section{Freud in Hebrew}

The collectivist ethos that had developed in the Jewish settlements in Palestine - that peculiar blend of the Central European youth movement romanticism and of the Russian version of the New Man - was not found solely within Ha-Shomer Ha-Zair.

So that should the comparison between the individual's mental ailments and the plight of the nation not rest only on metaphors, a scientific connection had to be established between the private and the public spheres, between individual sickness and collective disturbances. This theory laden pathway was shown by Freud's sociological essays. According to the Freudian approach, the individual psyche contained in shorthand the whole history of humanity - from the childhood oedipal romance within the family to the archaic fantasy world inherited 
from the forebears. Freud developed his political and social theories of liberalismauthoritarianism-patriarchalism in three of his texts - Totem and Taboo of 1913, Group Psychology and the Analysis of the Ego of 1921, and Moses and Monotheism of 1939. These were also the texts through which Hebrew-language readers of the period would become familiar with psychoanalysis. Freud may have found it difficult to understand why the Hebrew Teachers Association in Palestine had chosen his Group Psychology and the Analysis of the Ego to be his first work translated into Hebrew: "I hold in my hands with utmost satisfaction the translation of Group Psychology into our Holy Language. As ignorant child of pre-Zionist times, I am not able to read this language, but I rejoice at your assurance that this translation will serve a readership to whom the German or English edition would have been entirely devoid of meaning. Your assurance that this translation of a small article chosen from a small collection of my contributions will not remain solitary is even filling me with greater delight. I may thus hope that the astonishment which uses to be called out by the first encounter of a psychoanalytic book, will vanish soon in favor of another, more friendly attitude." 13

An essay operating in a positivist fashion with the terms of drive in order to describe the process, by which the individual becomes attached to society, seemed to cater to the needs of the educators in Palestine. Freud's language, although devoid of ideology, was entirely compatible with the world-view of these pedagogues. It provided the scientific underpinning for the collectivist self-understanding of the members of the Yeshuv. The individual was recognized only when he represented the desire to unite with the group members and to improve the group's cohesion. A reading of this work was recommended especially for those "who took part in nationalist propaganda and in the dissemination of new ideas," claimed one of the reviews written in honor of its publication (Strikovsky, $1928 \mathrm{in}$ : Rolnik, 2012). ${ }^{14}$

The call to shut off Freudian theory from its bourgeois notions characterized a number of critiques published in the same year, which saw the Hebrew publication of Totem and Taboo in 1936. An article in one of the main journals of the labor movement called upon the Hebrew reader to "review and scrutinize the sociological psychoanalytic research and draw from it all that is important and helpful to our proletarian world-view." (Ben-Shaul, 1939 in: Rolnik, 2012 p. 170). Nevertheless, Yehuda Dvir Dvossis, the translator of the work, had his own agenda. Indeed, he deemed it important to base Freud's text on sources of Jewish origin. He therefore informed Freud of his intention to add to the translation of Totem and 
Taboo a number of comments from the Biblical and Talmudic literature in order to "strengthen and verify your claims, and to occasionally show them in a new light." 15

As could be expected, many of Freud's critics were strongly interested in the question concerning the relation between the Jewish origins of the founder of psychoanalysis and his teachings. Some even went so far as to claim that his concept of repression should be viewed as an acknowledgment of his faith. In 1942 the poet Ben-Shalom published a truly distraught article (it coincided with the publication of the Hebrew translation of Psychopathology of Everyday Life). This article claimed that the "repressed Jewishness" of Freud and of his contemporaries was at the basis of psychoanalytic theory, and that "the secret of Freud's life and work is the secret of all the Anusim [forced converts]" (Ben-Shalom, 1942, cf. Rolnik, 2007, p. 269).

The brunt of the rage of Freud's readers during the period of World War Two was directed towards Moses and Monotheism. Freuds last work provided the proof that the founder of psychoanalysis had an intellectual agenda which grossly diverged from that of most of his Hebrew readers in Mandate Palestine. Enraged responses were voiced against the historical thesis of the Egyptian origins of Moses, the founding figure of the Jewish people. In an open letter entitled Sigmund Freud and "Made in Israel," the orchard owner Nachum Perlman attacked Freud's attempt to "cast our spiritual assets into the depths of the ocean and to open our spiritual affairs before the eyes of those entirely foreign to Judaism." 16

A blend of enthusiasm, outrage and misunderstanding characterized the initial reception of Freud's works by readers in Zion. Allegorically, passion and frustration also stood at the heart of the first clinical paper which originated from Tel-Aviv and which was accepted for publication in an official journal of the psychoanalytic movement. It bore the title An analysis of a Coitus Interruptus Dream (cf. Jacoby, 1927).

It is in his correspondence with those who were not among his disciples that Freud generally comes across as a curious and generous interlocutor, whose fame had not gone to his head. He does not make do with pleasantries, but rather treats even the unfounded assumptions of laymen seriously, and makes use of them to clarify his ideas.

Dr. Yochanan Lewinson, a dentist who immigrated from Berlin to Palestine in 1933, where he joined kibbutz Givat Brenner, wanted to thank Freud, first and foremost. Thanks to psychoanalysis, he reveals in his letter, he was able to make a number of fateful life decisions and give up an academic career in Germany in favor of life in a cooperative community in the Land of Israel. 
Lewinson dealt with three main professional issues in the letter he sent Freud on August 5, 1936, that refer to the first chapters in the series New Introductory Lectures on Psychoanalysis, which Freud had published three years earlier. The first issue pertains to the status of night terror - a sleep disorder in which a person quickly awakens from sleep in a terrified state - in basic psychoanalytic dream theory.

These dreams, which rob the slumber of those who are suffering with traumatic neurosis (or in current psychiatric jargon, post-traumatic stress disorder), ostensibly contradict the fundamental formula of dream interpretation, according to which the primary motive for dreaming is to fulfill unconscious wishes. Despite the difficulty one may have in identifying any pleasurable wish in night terrors, Lewinson, like Freud, was hoping to find a place for the phenomenon within the conceptual framework of the standard historic dream theory, and pointed to the mental function that these painful experiences could serve in those who suffer from traumatic neurosis. These dreams, he contends, reconstruct the traumatic experience so as to allow the mental mechanism to release the emotional excess that is one of the hallmarks of the traumatizing situation.

The second issue Lewinson discussed in his letter to Freud related to another chapter in the New Introductory Lectures. Under the heading Dreams and Occultism, Freud discusses, among other things, the phenomenon of telepathy. During the bloody events of the 1936-39 Arab Revolt, Lewinson had reached the conclusion that a handful of Arab villagers in Palestine were blessed with telepathic powers: "I have no doubt that the only method of transmitting information that was available to the Arabs was by means of thought transference. There is evidence that certain people among them broadcast the messages while others receive them... I can imagine that these phenomena might constitute an especially fruitful field of research for the psychoanalyst, but he must be familiar with the language and culture of the Arab population in question."

The failed attempts to establish clinical psychoanalysis in Mandate Palestine during the 1920s indicated that bringing the Freudian theory to clinical circles and guarding it from a downgrade to some cultural and/or ideological curiosity would require a special brand of analysts whose identity would not fall short of their Zionist convictions. Max Eitingon, for that matter, certainly epitomized this profile. 


\section{German Speaking Analysts in Palestine: an Outline of Psychoanalytic Prosopography}

The second, decisive phase in the establishment of psychoanlysis in prestate Israel as a therapeutic discipline began with the onset of the Fifth Aliya, the large migratory wave to Palestine which started in 1929 and continued until the outbreak of the Second World War. Although it was again driven mostly from Eastern Europe, it brought with it some 90000 German speaking Jews who fled Europe following the Nazis' rise to power in 1933, and following Germany's annexation of Austria and the Sudetenland.

Max Eitingon (1881-1943), who cofounded with Karl Abraham the Berlin psychoanalytic Polyclinic in 1920 and the Palestine Psychoanalytic Society in 1933, certainly epitomized the new combination of a committed political Zionist who is also an unyielding adherent of psychoanalysis in its clinical and lesser ideological version. Until his emigration from Berlin, the Russian born son of the Pelzkönig from Leipzig (king of the fur industry) was mostly known by his associates as the first analyst who underwent a training analysis by the old master; as Freud's most loyal representative in the Secret Committee and as the movement's main financial benefactor. By 1933 he had assumed a number of important administrative functions and key positions in the psychoanalytic movement, in addition to his historically most significant role as the founder of the first psychoanalytic out-patient clinic, which was also the psychoanalytic movement's most esteemed training facility. Funded predominantly from Max Eitingon's own resources, the Berlin Psychoanalytic Policlinic offered poorer sections of the population therapeutic counseling either free of charge or at reasonable prices (cf. Danto, 2005). This facility also served as a training institution for the new generation of psychoanalysts, and was later responsible for the development of the fundamental structures, still valid today in most analytic training institutes and known as The Eitingon Model, of a regular, institutionalized training resting on the three pillars of training analysis, theoretical instruction, and control analyses (cf. Schröter, 2002).

Aryanization all over the Reich advanced rapidly. Two of Eitingon's nonJewish colleagues hurried to Vienna in order to convince Freud to appoint them as legal directors of the Institute. But on August 23, 1933, Freud wrote Ernest Jones that "we have lost Berlin." 17

Eitingon left Berlin and reached Palestine in October 1933, holding a letter of recommendation from Freud designed to facilitate the receipt of a work permit. Although generous and sympathetic in his letter, Freud did not fail to mention his hopes that Eitingon's departure to Palestine be only temporary. ${ }^{18}$ The psychoana- 
lytic immigrant soon gathered a handful of former colleagues from Berlin. Within four weeks from his arrival, he reported to Freud that the Palestine Psychoanalytic Society (PPS) had been founded. Anna Freud's letter to Jones put the news into its proper historical perspective: "My father had a letter from Eitingon today. You will soon hear from him about the formation of a new group in Palestine. The members are mostly or all old Berlin members. New groups used to be a pleasure. They are not just now." ${ }^{19}$

Eitingon's letters and public persona indicate that life in Palestine did not turn him into a disillusioned Old Zionist or an idealistic New Zionist. Although he supported the Palestine Communist Party (PKK) for many years, he was certainly not an Anti-Zionist. ${ }^{20}$ He belonged to the fairly small circle of Berlin Zionists, whose successful acclimatization in Palestine was aided by a strong sense of solidarity with the east-European socialist version of Zionism. As his letters to Anna and Sigmund Freud show, Eitingon's identification with Constructive Zionism differed significantly from Freud's somehow loose solidarity with the fate of the Jews in Palestine, or from Einstein's mainly spiritual and cultural version of Zionism.

Regarding the absorption of the psychoanalysts in Palestine, it is important to note that the founders of the PPS were nearly all German-speaking professionals who had left their European countries. Anna Smilansky, Moshe Wolf, Ilya Shalit, Max Eitingon and Fania Lowetzky (the sister of the Russian philosopher Lev Shestov, who also called himself Léon Chestov) were Russian native speakers. The years spent in Germany as students in Marburg, Freiburg im Breisgau or Heidelberg or as practicing psychoanalysts in Zurich, Vienna or Berlin, had not weakened their ties to Russian culture and to the east European version of Jewish ethnicity. In other words, work at the Psychoanalytic Institute in Berlin on the one hand and the gloomy political situation which had forced their emigration on the other hand, can be seen in hindsight as necessary conditions for the foundation of the Palestine Psychoanalytic Institute, but these conditions were not yet sufficient. The Russian roots of these analysts undoubtedly played a role in their identification with Zionism. It may thus have strongly motivated their choice of Palestine as a place suitable for immigration.

That same group of analysts who had chosen to continue their professional activities in Palestine manifested the creation of an ethos, or an alternative narrative, which widened the circle of reference and the historical memories of Freud's students beyond the small group of immigrants from Germany. Eitingon and his colleagues were interested in viewing Freud's works not only as the German version of the Jewish canonical works, but also as a canonical work of reference for 
immigrants from Russia, Poland and Galicia, and even for the old Jewish settlements in Palestine. Similarly, the population treated was not only comprised of German speakers. The analysts from Berlin did not rely on the willingness of the German émigrés to adopt psychoanalysis, as though it were a Germanic spiritual asset facilitating adaptation to the Palestine environment. The fact that over $30 \%$ of the 130 analyses taking place at the Jerusalem Institute in the first seven years subsequent to its establishment were done in either Yiddish or Hebrew supports the hypothesis of the achievements of Eitingon and his colleagues to increase the number of persons interested in psychoanalysis (cf. Brandt, 1941). Indeed, several attempts, which all failed, to bring psychoanalysis to the Hebrew University would serve the émigré analysts as a continual reminder that the German model, on which the Hebrew University was founded and based, could hardly make Hebrew academe more receptive to Freud's ideas any more than German academe had been.

\section{Berlin in Jerusalem}

Notwithstanding the need to open up the analytic institute to wider sections of the population, Eitingon's involvement as the founder of the Berlin Institute enabled the immigrant analysts to foster a shared belief that eased their adaptation to the new homeland. The analysts in Mandate Palestine saw themselves as the rightful heirs of the Berlin Institute, whose activities, though on a much smaller scale, had now been transferred to Jerusalem. A great number of pictures and furniture, all belonging to Eitingon, had been shipped from the Berlin Institute to Jerusalem; the Berlin Institute's library, also mostly consisting of Eitingon's huge private collection, reached Jerusalem without loss, as did the Institute's files stemming from Berlin. These were the material ingredients which enhanced the construction of the self-image the founders of the Jerusalem Institute shared. According to this image, what had come to an abrupt and painful end in Berlin had found its continuation in Jerusalem. This implied the notion that the Berlin Institute, though still in existence, had in fact lost its connections with the psychoanalytic movement, both formally and materially. The rapid access of the small Jerusalem group to the International Psychoanalytic Association (IPA) - a process which under normal historical circumstances would have taken years -, was an important factor in creating a basic feeling of continuity, which was so crucial to the émigré analysts in their new environment. The transformation of the Institute in Jerusalem into the offspring of the Berlin Institute had thus a great impact on both the analysts and their analysands, who felt that they had succeeded in creating for themselves, under the tragic circumstances which had led to their arrival in Palestine, a Berlin 
microcosm that eased their acclimatization to their new home. Additionally, the formal organizational process yielded some desired effects to the extent of increasing the prestige of the immigrants from Europe. From this moment on, the analysts were no longer merely agents of knowledge - they had become the embodiment of psychoanalytic knowledge as such.

A look at the regulations they had formulated for the group reveals that, in their wish to ensure that none would use the name of Freud's theory in vain, Eitingon and his colleagues agreed to add an unusually strict clause. It stipulated that each member who wished to give a public lecture on any psychoanalytically relevant topic, inform in advance the committee from which he or she had to receive consent. ${ }^{21}$

The demand for the services of analysts was on a constant rise. The interest the Hebrew-language newspapers showed in the fate of Freud's family following the annexation of Austria even increased the visibility of the immigrant analysts working in Mandate Palestine - a fact to which Eitingon attributed the large rise in number of persons who sought therapy in the second half of 1938. Although some of the patients were disappointed that the new "healers of the soul" did not offer them charms and potions, the analysts, in turn, showed much flexibility and often agreed to incorporate hypnotic therapy into classic psychoanalytic treatment; thus, therapies would be significantly shortened.

It is likely that demographic changes do not suffice for providing a good explanation for the considerable interest people were taking in that period in psychoanalysis as a method for relieving an individual's sufferings. Clearly, as the ethnic and social composition of the population in Mandate Palestine underwent changes, the number of requests to undergo analysis grew. But this phenomenon of growth is somewhat more complex. Psychoanalysis held the promise that reality, however harsh and painful it might be, was never dissociated from one's inner, mental, symbolic world. When familiarizing oneself with this inner world as well as turning it into something less intimidating, encounters with reality would become easier and the ability to cope with it would improve. Paradoxically, when reality was shaped by an essentialist fascist ideology, which discarded the dynamic concept of the mind, psychoanalysis offered the immigrant the ability to reexamine the borders between inside and out, between her inner fantasy world and the reality outside of it.

The few analysts who sought shelter in Palestine had to present themselves first before Eitingon, so that he might evaluate "their level of suitability for the unique conditions of this country." ${ }^{22}$ Two renowned analysts such as Wilhelm 
Reich and Theodore Reik, who had roamed throughout Europe during the thirties, might well also have arrived in Palestine already in 1933, if it hadn't been for Eitingon's objection. For he was concerned with the Communist identity of Reich and the notorious rebelliousness of Reik. The latter, however, did arrive in Palestine for a visit; he lectured before the members of the Jerusalem group, but his critical approach towards Jewish customs, as it came to be expressed in his books, not only were far from Eitingon's personal leanings, whose own affinity to the Jewish tradition was growing only now, but might also have endangered the neutral and unobjectionable public image the former leader of the Berlin group attempted to foster amongst his fellow analysts in Mandate Palestine (Rolnik, 2008).

Anna Freud was extremely interested in the fate of the group working in Tel Aviv, Jerusalem, and some other spots in the Palestinian Levante. Eitingon, practical and often reserved, wrote her of his journeys in the country, of his memorable excursions into the desert and at Petra, the intoxicating smells of the citrus trees blossoming, and the excellent weather conditions. Often he sent to Vienna crates of oranges or grapefruits and received news telling him that "such grapefruits, unlike any sold in Vienna, even Papa devours with rapture, although he is forbidden to eat fruit." 23

\section{Classic Analysis}

The analysts had plenty of patients to treat even in the two years subsequent to their immigration to Mandatory Palestine. Eitingon at the time was treating nine patients. The small psychoanalytic society managed somehow to maintain an image of solidarity even during the periods when some members had to face a disciplinary committee under the claim that they had strayed from the Classic Freudian psychoanalysis. This was an accusation often hurled at one another within the society; it even helped to keep alive ancient rituals and memories from Berlin and Vienna. The seminars for teachers and pedagogues, which were held by some fellows of the Psychoanalytic Institute, increasingly became more suspect of straying from the original spirit of psychoanalysis. Moishe Wolff, who became Eitingon's successor as chairman of the analytic association, was apparently shocked by what Fania Lowetzky wrote in 1950 in the popular newsletter for pedagogues Mental Hygiene; he suspected her to instruct the kindergarten teachers she trained to "spoil the children." Subsequently the psychoanalyst was summoned to appear before a special committee and to prove that her theoretical positions did not stray from those of classic Freudianism. But having refused to appear before the committee, she was stripped of her training position. 
What was that classic analysis that was supposed to unite the members of the Jerusalem Institute, and which, if not upheld, was grounds to question the very use of the word psychoanalysis? Arguably, this question, which had accompanied the psychoanalytic movement since Freud had written On the History of the Psychoanalytic Movement in 1914, received a special significance after the emigration of the psychoanalysts from Europe and the closing of the two Institutes in Berlin and Vienna. The term "classic" may have carried with it an additional symbolic and psychological meaning for those who had been severed from their work environment, their language and their culture. Classic psychoanalysis served the émigrés as an alternative identity signifier during the years in which they had to establish themselves in their new environment (Rolnik, 2015).

But regardless of how classic each and every analyst wished to perceive her/ himself, in Mandate Palestine the old battles of psychoanalysis had to be fought again and again on a daily basis. Strong opponents to psychoanalysis such as Martin Buber or Gershom Scholem had to be dealt with cautiously. Not a single critique of Freud's theory that appeared in the Hebrew press would be ignored. Financial and professional support was given by Eitingon on a regular basis to various welfare projects such as Youth Aliyah, the organization that rescued 22000 Jewish children from the Nazis during the Third Reich.

Internal struggles and theoretical purges had accompanied the everyday life of the psychoanalytic associations from their very establishment on. Yet, in what ways was the Institute in Palestine different from that in Vienna or Berlin? Even Anna Freud wanted to know whether the future of the Jewish nation in the Land of Israel would also affect the state of psychoanalysis, and whether the new ties to the land and earth would cause the Berlin analysts in Palestine to suddenly become landowners or even farmers. The idyllic descriptions of the nature and the views sent by Eitingon echoed in Anna Freud's heart: psychoanalysis and oranges, Jerusalem figuring in one of her dreams: "Last night I had a vivid dream of Jerusalem. But it was a mixture of Vienna Forrest and Berchtesgaden - it seems that my imagination cannot reach any further then that." ${ }^{24}$

The gradual dissemination and acceptance of analytic practice in the society in Mandate Palestine made it necessary to take several formal questions and issues of judicial precedence into consideration. Questions of the minimum fees analysts would charge their patients nearly led to a clash between the psychoanalysts and the Physicians' Union, one of the most powerful organizations in the Yishuv; at last a compromise was reached, however. It permitted the analysts to preserve the unique philanthropic character of the Institute and give, in cases of need, gratis 
treatment, whilst the private clinics would abide by the minimum fees set by the Physicians' Union. ${ }^{25}$

Modern Jewish nationalism, as radical and revolutionary as it may have been during its early years, was not overly tolerant towards those who questioned the basic tenets of Zionism. The amalgam of utopian ideals with actual Zionist activities led to a renouncement of everything not directly identified with constructivist activism. More deeds, less words had been the motto of the immigrants in Palestine who viewed philosophy, criticism, or reflection as a sort of antithesis to change and construction (cf. Shapira, 1996). As we have seen, the critical psychoanalytic discourse of the Ha-Shomer Ha-Zair educators in fact rapidly distanced psychoanalysis from the individual and turned it into an instrument for the group's ideological needs. Paradoxically, in an ideological environment that tended to appropriate the individual's private sphere for the benefit of public interests, Freudian psychoanalysis offered the immigrant the ability to reexamine the borders between inside and out, between his inner world and the reality outside of it.

This raises a question over whether the price paid for the establishment of psychoanalysis in Palestine did not entail relinquishing its critical aspects. Did the desire to ensure a wide consensus regarding the merits of Freud's theory in the collectivist and ideologist atmosphere of pre-state Israel bring Eitingon and his successors to steer psychoanalysis onto a pronounced anti-intellectual path, leading to a narrowing of its horizons?

The formative years of psychoanalysis in Israel were consequently shaped by a perpetual conflict. While popular psychoanalytic discourse worked ceaselessly towards defusing the social pessimism that was part of Freud's works (as well as Freud's well-documented skepticism regarding political Zionism), it was left for the analysts to safeguard the therapeutic position of psychoanalysis.

While inwardly Eitingon demonstrated much flexibility in allowing the reality in Palestine and the Nationalist Jewish sentiments to influence the lecture program at the Institute, in the yearly reports sent to the International Psychoanalytic Association he particularly emphasized psychotherapy as the mainstay of the Institute's interests.

Beginning in the 1960s, and to the present day, Israeli psychoanalysts have published a large number of articles and books devoted to the psychological effects of the Holocaust and on the clinical treatment of survivors and their children and grandchildren. These works consider the implications of the trauma of the Holocaust for Israeli society, the Israeli-Palestinian conflict, and the relations between Israelis and Germans. It looks as if Israeli clinicians embraced the idea of 
trans-generational transmission of trauma as a way to counterbalance the general reluctance of Israelis to acknowledge the presence of Jewish history and past in their self-understanding.

Currently celebrating its eightieth anniversary, the Israel Psychoanalytic Society finds itself thriving, both in numbers of members and candidates. Representatives of all major psychoanalytical orientations are to be found in the membership. If analysts in Israel seem to have relinquished the search for a common ground in matters of theory or technique, they have not given up the desire to remain under the same roof, however loosely associated. Contemporary psychoanalytic discourse in Israel offers still more food for thought on the relationship between science and ideology, and between political culture and analytic theory. Consider, for instance, the pronounced trauma-centrism of the analytic discourse in present-day Israel. The vast majority of younger analysts in Israel today are inclined in their clinical work toward psychoanalytic models of the mind that emphasize the role of actual trauma in mental life. The imagined patient of Israeli psychoanalysis seems to be a fairly passive individual, mostly reactive to his environment and, therefore, hardly accountable to his interiority and his mind.

Such theorizing tends to portray the patient as a passive template on which social atrocities or the shortcomings of his significant others are inscribed, rather then as an active agent. It is a trend that has accompanied a steady decline in interest in the dynamic unconscious, in primary aggression, and in promoting the patient's sense of responsibility for both the creative and the destructive forces in his psyche. Could it be that this trend is itself multiply determined, and perhaps reinforced, by an Israeli political culture that promulgates the notion that all evil comes from outside?

These are difficult times for psychoanalysis everywhere. But working analytically at the frontier of militant nationalism and religious fanaticism poses an even greater challenge for those seeking to enhance their patients' sense of personal agency and encourage them to translate their concrete reality into meaningful psychic experience.

\section{Bibliography}

Ash, Mitchell G. \& Söllner, Alfons (eds.). (1996). Forced Migration and Scientific Change: Emigre, German-Speaking Scientists after 1933. Cambridge and New York: Cambridge University Press.

Ash, Mitchell G. (1991). “Central European Emigré Psychologists and Psychoanalysts in the United Kingdom”, in: Werner E. Mosse, (ed.), Second Chance: Two 
Centuries of German-Speaking Jews in the United Kingdom. Tübingen: Mohr. pp. 101-20.

Bergman, Shmuel Hugo [also: Bergman, Hugo]. (1985). Tagebücher \& Briefe. Volume I: 1901-1948; Volume II: 1948-1975. Edited by Miriam Sambursky, with an introduction by Nathan Rotenstreich. Frankfurt am Main: JüdischerVerlag/ Athenäum.

Berkowitz, Michael. (1993). Zionist Culture and West European Jewry before the First World War. Chapel Hill, NC: University of North Carolina Press.

Bettelheim, Bruno. (1969). The Children of the Dream. New-York: Macmillan

Boyarin, Daniel. (1997). Unheroic Conduct: The Rise of Heterosexuality and the Invention of the Jewish Man. Berkeley: University of California Press.

Brandt, Margareta. (1941). Unpublished Report on the first Seven Years of the Jerusalem Psychoanalytic Institute. Eitingon Collection, Israel State Archives, Jerusalem.

Brunner, Jose. (1991). The (Ir)Relevance of Freud's Jewish Identity to the Origins of Psychoanalysis. Psychoanalysis and Contemporary Thought, 14, 655-684.

Buchholz, Hartmut. (2008). “... ich wäre mir ohne sie gar nicht denkbar”. Wolfgang Hildesheimer und die Psychoanalyse. Luzifer Amor, 21 (41),141-52.

Bunzl, John. (1992). Siegfried Bernfeld und der Zionismus. In Karl Fallend \& Johannes Reichmayer (eds.), Siegfried Bernfeld oder die Grenzen der Psychoanalyse. Frankfurt am Main and Basel: Stroemfeld Verlag.

Bunzl, Matti. (1997). Theodor Herzl's Zionism as Gendered Discourse. In Theodor Herzl and the Origins of Zionism, ed. by Edward Timms and Ritchie Robertson, 74-86. Edinburgh: Edinburgh University Press.

Cohen, Uri. (2006). The Mountain and the Hill: The Hebrew University of Jerusalem During Pre-independence Period and Early Years of the State of Israel (Heb.). Tel-Aviv: Am Oved

Damousi, Joy. (2005). Freud in the Antipodes. A Cultural History of Psychoanalysis in Australia. Sydney: UNSW Press.

Danto, Elizabeth Ann. (2005). Freud's Free Clinics: Psychoanalysis and Social Justice, 1918-1938. New York: Columbia University Press

Decker, Hannah. (1977). Freud in Germany: Revolution and Reaction in Science, 1893-1907. New York: International Universities Press.

Dotan, Shmuel. (1991). Adumim b'erez Israel. Kfar Saba: Shavna Hasofer Publishers (Heb.). 
Eder, David. (1924). Psychoanalysis in Politics. In E. Jones (ed.), Social Aspects of Psychoanalysis: Lectures Delivered under the Auspices of the Sociological Society (pp. $141 \mathrm{ff}$.). London: William \& Norgate.

Efron, John. (2001). Medicine and the German Jews: A History. New Haven: Yale University Press.

Ekstein, Rudolf. (1979). Siegfried Bernfeld: Sisyphus or the Boundaries of Education. In: F. Alexander, S. Eisenstein \& M. Grotjahn (eds.), Psychoanalytic Pioneers (pp. 349-368). New York.

Etkind, Alexander. (1997). Eros of the Impossible: The History of Psychoanalysis in Russia. Oxford: Westview.

Fenichel, Otto. (1998). 119 Rundbriefe in 2 Bänden. Ed. by Johannes Reichmayr and Elke Mühlleitner. Frankfurt am Main and Basel: Sreoemfeld Verlag.

Fermi, Laura. (1968). Illustrious Immigrants: The Intellectual Migration from Europe, 1930-41. Chicago: The University of Chicago Press.

Freud, Sigmund. (2004). Sigmund Freud-Max Eitingon. Briefwechsel 1906-1939. Ed. by Michael Schröter, 2 vols. Tübingen: edition diskord.

Gilman, Sander. (1993). The Case of Sigmund Freud: Medicine and Identity at the Fin de Siècle. Baltimore: The John Hopkins University Press.

Gluzman, Michael. (1997). Longing for Heterosexuality: Zionism and Sexuality in Herzl's Altneuland. Theory and Criticism, 11, 145-162 (in Hebrew).

Goren, Arthur. (1982). Dissenter in Zion: From the Writings of Judah L. Magnes. Cambridge, Mass: Harvard University Press.

Hale, Nathan. (1995). Freud and the Americans: The Beginnings of Psychoanalysis in the United States, 1876-1917. Oxford: Oxford University Press.

Hart, Mitchell. (2000). Social Science and the Politics of Modern Jewish Identity. Stanford, CA: Stanford University Press.

Hartnack, Christiane. (1990). Vishnu on Freud's Desk: Psychoanalysis in Colonial India. Social Research, 57(4), 923-949.

Haynal, Andre. (1994). Central European Psychoanalysis and Its Move Westwards in the Twenties and Thirties. In Ehlers, H. \& J. Crick (eds.): The Trauma of the Past Remembering and Working Through. Lecture Series Organised by the Goethe-Institut London in January 1993 (pp. 101-116). London: Goethe Institut.

Hinshelwood, Robert. (1995). Psychoanalysis in Britain: Points of Cultural Access. 1893-1918. International Journal of Psycho-Analysis, 76, 135-151.

Hobman, J. B. (1945). David Eder: Memoirs of a Modern Pioneer. London: Victor Gollancz. 
Hoffer, Willy. (1981). Early Development and Education of the Child. Ed. by Marjorie Brierly (pp. 123-144). New York: Aronson.

Hollander, Carro. (1990). Buenos Aires: Latin Mecca of Psychoanalysis. Social Research, 57(4), 889-919.

Jacoby, Curt. (1927). Analyse eines Coitus-Interruptus-Traumes. Internationale Zeitschrift für Psychoanalyse, 13, 458-459.

Kloocke, Ruth.(2002). Mosche Wulff. Zur Geschichte der Psychoanalyse in Rußland und Israel. Tübingen: edition diskord.

Kurzweil, Edith. (1996). Psychoanalytic Science: From Oedipus to Culture. In Ash, Mitchel. G. \& Alfons Söllner (eds.), Forced Migration and Scientific Change. German Speaking Scientists and Scholars after 1933. Cambridge: Cambridge University Press.

Liban, A. \& Goldman D. (2000). Freud Comes to Palestine: A Study of Psychoanalysis in a Cultural Context. International Journal of Psycho-Analysis, 81, 893-906.

Makari, George. (2008). Revolution In Mind: The Creation Of Psychoanalysis. New York: Harper Collins.

Margalit, Elkana. (1971). Hashomer Hazair-From Youth Community to Revolutionary Marxism (1913-1936). Tel Aviv: Tel Aviv University. (in Hebrew).

Martin, Jay. (1986). Permanent Exiles: Essays on the Intellectual Migration from Germany to America. New-York: Columbia University Press.

Miller, Martin. (1998). Freud and the Bolsheviks. New Haven, CT: Yale University Press.

Mintz, Matityahu. (1995). Pangs of Youth - Hashomer Hazair 1911-1921. Jerusalem: Hassifriya Haziyonit. (in Hebrew).

Moses, Rafael. (1998). A Short History of Psychoanalysis in Palestine and Israel. Journal of the American Academy of Psychoanalysis, 26, 329-341.

Peled, Rina. (2002). “The New Man” of the Zionist Revolution: Hashomer Haza'ir and his European Roots. Tel-Aviv: Am Oved and the Koebner Center for German Studies. (in Hebrew).

Peters, Uwe. (1992). Psychiatrie im Exil. Die Emigration der dynamischen Psychiatrie aus Deutschland 1933-1939. Düsseldorf: Kupka.

Rapaport, David. (1958). The study of Kibbutz Education and its Bearing on the Theory of Development. The American Journal of Orthopsychiatry, 28, $587-597$.

Rolnik, Eran. (2002). Psychoanalysis Moves to Palestine: Immigration, Integration and Reception. In John Bunzl \& Benjamin Beit-Hallahmi (eds.), Psychoanalysis, Identity and Ideology. Critical Essays on the Jewish/Israeli 
Case (pp. 114-176). Boston/Dordrecht/NewYork/London: Kluwer Academic Publishers.

Rolnik, Eran. (2008). Why is it that I See Everything Differently? Reading a 1933 Letter from Paula Heimann to Theodor Reik Regarding Psychoanalytic Technique. Journal of the American Psychoanalytic Association, 56(2), 409-430.

Rolnik, Eran. (2012). Freud in Zion: Psychoanalysis and the Making of Modern Jewish Identity. London: Karnac.

Rolnik, Eran (2015) After Babel: Reflections on Reading and Translating Freud. The Psychoanalytic Quarterly, LXXXIV (2), 307-330.

Shapira, Anita. (1996). Native Sons. In Jehuda Reinharz and Anita Shapira (eds.), Essential Papers on Zionism (pp. 791-821). New-York: New York University Press.

Spiegel, Rose. (1986). Freud's Refutation of Degenerationism: A Contribution to Humanism. Contemporary Psychoanalysis, 22, 4-24.

Steiner, R. (2011). In All Questions, My Interest is Not in the Individual People but in the Analytic Movement as a Whole. It Will Be Hard Enough Here in Europe in the Times to Come to Keep it Going. After All, We are Just a Handful of People Who Really Have That in Mind. Int. J. Psycho-Anal. 92, 505-591.

Sternhell, Zeev. (1998). The Founding Myths of Israel: Nationalism, Socialism, and the Making of the Jewish State. Princeton: Princeton University Press.

Timms, E. \& Segal N. (eds.). (1988). Freud in Exile: Psychoanalysis and its Vicissitudes. New Haven and London: Yale University Press.

Turkle, Sherry. (1992). Psychoanalytic Politics: Jacques Lacan and Freud's French Revolution, $2^{\text {nd }}$ edition. New York: Guildford Press.

Velikowsky, Emanuel. (1934). Kann eine neuerlernte Sprache zur Sprache des Unbewußten werden? Wortspiele in Träumen von Hebräisch Denkenden. Imago, 234-239.

Windhager, Günther. (2002). Leopold Weiss alias Muhammad Asad: Von Galizien nach Arabien 1900-1927. Vienna: Böhlau Verlag.

Wistrich, R. \& Ohana, D. (eds.). (1995). The Shaping of Israeli Identity: Myth, Memory, and Trauma. London: Frank Cass.

Wittenberger, Gerhard \& Tögel, Christfried (eds.). (1999). Die Rundbriefe des "Geheimen Komitees». Tübingen: edition diskord.

Wulff, Mosche. (1928). Bemerkungen über einige Ergebnisse bei einer psychiatrisch-neurologischen Untersuchung von Chauffeuren. Internationale Zeitschrift für Psychoanalyse, 14, 27-242. 


\section{Annotations}

1 Letter of Freud to Abraham, May 3, 1908, in: Freud \& Abraham, 1965.

2 Freud in 1907, in: Nunberg \& Federn,1979. vol 1, 94.

3 Eitingon's own analysis with Freud in 1909 lasted just six weeks; it is considered the first training, or didactic, analysis in the history of psychoanalysis.

$4 \quad$ Letter of Ernest Jones, December 7, 1920, in: Wittenberger \& Tögel (1999), 202.

5 Letter of Freud to Alter Druyanov, October 3, 1910 (unpublished, Freud Museum, London): «Es is mir sehr erfreulich zu hören, daß mein Buch über die Traumdeutung eifrige und verständnisvolle Leser in so weiter Ferne gefunden hat. Auf die Äußerungen des Talmud über die Traumprobleme bin ich wiederholt aufmerksam gemacht worden. Ich muß aber sagen, daß die Annäherung an das Verständnis des Traumes bei den alten Griechen eine weit auffälligere ist.»

6 See also Dorian Feigenbaum's Curriculum Vitae., unpublished document, the A.A Brill Library and Archive, NewYork Psychoanalytic Institute. Eder himself, it should be noted, was the first analyst to address the issue of Psychoanalysis and Politics in a paper published in 1924.

$7 \quad$ Founded in 1913 in Galicia, Ha-Shomer Ha-Zair came into being as a result of the merger of Hashomer (The Guard), a Zionist Scouting group, and Ze'irei Zion (The Youth of Zion), an ideological circle devoted to the study of Zionism, left wing socialism, and Jewish history. The movement's ideology combined the ideas of the Marxist-Zionist Ber Borochov (1881-1917) with those of the German educational reformer GustavWyneken (1875-1964) as well as Baden Powell (founder of the Scout Movement) and the German Wandervogel movement. By the late 1920s, there were already four kibbutzim (collective settlements) founded by Ha-Shomer Ha-Zair, which banded together to form the Kibbutz Artzi (lit. Nationwide Kibbutz) federation; the movement also founded a political party which advocated a binational, Arab-Jewish solution for Mandatory Palestine.

8 From a talk sent by Meir Yaari from Palestine to Vienna, most likely at the end of February or in early March 1921; cf Mintz, 1995, $353 \mathrm{ff.}$

9 Ibid.

10 Hugo Bergman to Weltsch Robert, June 7, 1922, reproduced in Bergman 1985.

11 Bergman to Robert Weltsch, March 27, 1923, reproduced in Bergman 1985, XXX.

12 International Journal of Psycho-Analysis 1924, vol. 10, p. 101.

13 Freud to Yellin, the secretary of the Hebrew Teachers Union, September 14, 1928, unpublished, Freud Museum, London: «Mit besonderer Genugthuung habe ich die Übersetzung meiner Massenpsychologie in unsere heilige Sprache zur Hand genommen. Ich, unwissendes Kind einer vorzionistischen Zeit, kann sie leider nicht lesen, aber ich freue mich an ihrer Versicherung, dass diese Übersetzung einem Publikum dienen wird dem die vorhandene deutsche oder englische Ausgabe nichts gesagt hätte. Noch mehr beglückt mich Ihre Zusage, dass diese Uebersetzung einer kleinen aus der Schar meiner Arbeiten herausgegriffenen Schrift nicht vereinzelt bleiben wird. So darf ich hoffen, dass das Befremden, welches die erste Wirkung eines psychoanalytischen Buches zu sein pflegt, bald anderen und freundlicheren Einstellungen weichen mag.»

14 Cf. Zvi Strikovsky review of Freud's Group Psychology and Ego Analysis published in Shvilay Ha'chinuch [Heb] in 1928-1929, quoted in Rolnik 2012.

15 Dwosis to Freud, November 30, 1938, unpublished, Freud Museum, London: «In die Hebräische Ausgabe Ihres Buches wurden - in Form von Fussnoten - eine grosse Zahl von Zitaten aus der biblischen und der talmudischen Literatur aufgenommen, die Material zur Bestätigung und Bekräftigung der Behauptungen Ihres Buches enthalten und hie und dort auch dazu angetan sind, neues Licht auf sie zu werfen.» 
16 Perlmann to Freud, July 2, 1939.

17 Freud to Ernest Jones, August 23, 1933, reproduced in Freud \& Jones 1993, p. 91.

18 5.10.1933: «Ich bin der sicheren Überzeugung, daß seine [Eitingon's] Loslösung von der Stätte seiner bisherigen Tätigkeit nur einen Zwischenfall und kein Ende seiner für unsere Sache unschätzbaren Leistung bedeutet.» Freud, 2004, p. 869-870.

19 Anna Freud to Ernest Jones, November 7, 1933, unpublished, Archives of the British Psychoanalytic Society, London.

20 Shmuel Dotan, who wrote the history of the Palestine Communist Party (PKK), identified Eitingon as the main benefactor of the party during the 1930s and early 1940s (cf.Dotan, 1991, 385-387).

21 Statues of the Palestine Psychoanalytic Society, unpublished, Eitingon Collection, Israel State Archives, Jerusalem.

22 Max Eitingon to Ernest Jones, May 4, 1938, unpublished, Archives of the British Psychoanalytic Society, London.

23 Anna Freud to Max Eitingon, March 4, 1935, unpublished, Anna Freud Collection, Library of Congress.

24 Anna Freud to Max Eitingon, May 11, 1934, unpublished, Anna Freud Collection, Library of Congress.

25 Letters of Max Eitingon to the Hebrew Medical Association, February 5 and February 16, 1936, unpublished, Eitingon Collection, Israel State Archives, Jerusalem. 